\title{
An Annotated Bibliography of Recruiting Research Conducted in the U.S. Armed Services and in Foreign Services
}

Lisa M. Penney, Martha J. Sutton, and Walter C. Borman

Personnel Decisions Research Institutes, Inc.

\section{Selection and Assignment Research Unit Michael G. Rumsey, Chief}

U.S. Army Research Institute for the Behavioral and Social Sclences 5001 Eisenhower Avenue, Alexandria, Virginia 22333-5600

March 2001

Army Project Number

20262785A790

Personnel Performance and

Training Technology

Approved for public release; distribution unlimited. 